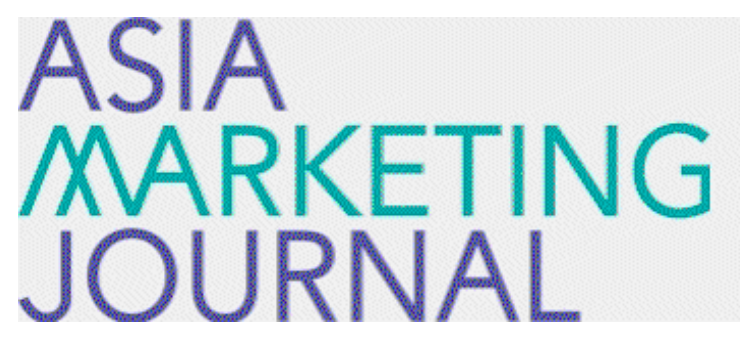

ASIA MARKETING JOURNAL

Volume 6 | Issue 2

Article 5

7-24-2004

\title{
첨단정보통신 신상품의 개발과 마케팅 전략
}

Ju Young Ro

Seong Yeon Park

Follow this and additional works at: https://amj.kma.re.kr/journal

Part of the Marketing Commons

\section{Recommended Citation}

Ro, Ju Young and Park, Seong Yeon (2004) "첨단정보톻신 신상품의 개발과 마케팅 전략," Asia Marketing Journal: Vol. 6 : Iss. 2 , Article 5.

Available at: https://doi.org/10.53728/2765-6500.1128

This Article is brought to you for free and open access by Asia Marketing Journal. It has been accepted for inclusion in Asia Marketing Journal by an authorized editor of Asia Marketing Journal. 


\title{
첨단정보통신 신상품의 개발과 마케팅 전략: KT의 〈네스팟〉 사례를 중심으로
}

\section{New Product Marketing Strategy of Hi-Tech Communication Services: KT NESPOT Case}

\author{
노 주 영(Ro, Ju Young)* \\ 박 성 연(Park, Seong-Yeon) ${ }^{* *}$
}

본 사례는 신규 정보통신 서비스인 KT 네스팟의 태동과 첨단기술 기반의 틈새적 서비스로부터 대 중적 서비스로 변화하려는 2003년 초까지의 약 1년 6개월에 걸친 마케팅 활동을 소개함으로써 첨단 정보통신 기술상품의 마케텅 전략을 살펴보았다.

첨단 정보통신 기술상품은 제품의 톡성상 시장 진입기에서 성장기로 넘어가는 전략이 특히 중요하 며, 이를 성공적으로 수행하기 위해 실시한 실제 마케팅 사례를 살펴보았다.

핵심개념: $\mathrm{KT}$ 네스갓, 첨단기술제품, 캐즘마케팅

\section{I. 새로운 초고속 인터넷 서비스의 태동배경}

\section{1 초고속 인터넷 서비스의 산업적 효과}

2002년 10월, 한국의 초고속 가입자가 1 천만 을 넘어섰다. IT 열풍은 한국을 초고속 인터넷 가입자 세계 1 위라는 인터넷 강국의 위치에 올 려 놓았다. 한국의 초고속 인터넷 서비스 시장
은 KT와 하나로 통신이 서비스를 제공한 1999 년부터 급성장하였으며, 경쟁업체에 비해 뒤늦 게 초고속 인터넷 서비스 시장에 뛰어든 $\mathrm{KT}$ 는 2003 년 초 500 만 가입자를 돌파하는 성과를 낳 으며 초고속 인터넷 시장의 선두주자로 올라서 게 되었다.

초고속 인터넷 서비스 상품의 성공은 네트워 크-단말-컨텐츠로 연계된 IT 산업의 선순환 도 미노 효과를 가져왔으며, 이에 관련된 산업 전 반의 폭발적 성장을 이끌어 내게 되었다. 고가 의 전자제품이자 특수 계층만의 전유물이었던

* KT 마케팅본부 서비스개발연구소 연구원(jyno@kt.co.kr).

** 이화여자대학교 경영대학 교수(sypark@ewha.ac.kr). 
〈그림 1-1〉 정보통신 서비스의 연계된 복합적 특성: 네트워크-단말-엔포테인먼트 서비스

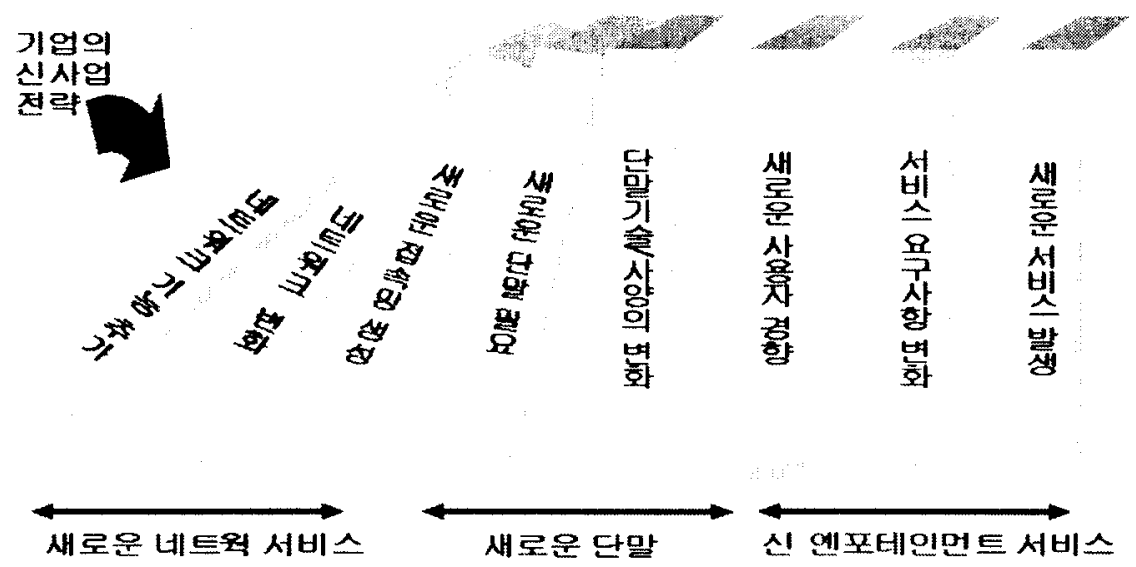

출처: KT 연구개발본부, Click@Cyberworld Forum 자료(1999. 10)

컴퓨터를 대중적 가전제품으로 자리잡게 함으 로써, 반도체 및 관련된 컴퓨터 부품산업을 발 전시키게 되었고, 인터넷 컨텐츠/포탈 벤처 기 업이 국내 IT 산업 발전의 중심 축으로 자리잡 게 되었다. 이처럼 새로운 네트워크 서비스가 새로운 단말을 발생시키고, 이에 적합한 엔포테

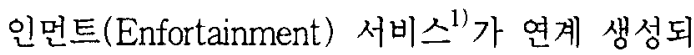
었다. 〈그림 1-1〉은 이러한 〈네트워크-단말-엔 포테인먼트 서비스>의 연계 개념을 설명한 것 이다.

\section{2 유선 초고속 인터넷 서비스 시장의} 포화와 새로운 서비스의 필요

$\mathrm{KT}$ 의 초고속 인터넷 서비스 상품인 '메가패 스 ADSL'은 1999년 이후의 폭발적 성장기를 지나 이미 성숙기에 접어들었다. 성숙기는 시장
의 성장이 둔화되고 경쟁이 날로 치열해져 새 로운 수익창출 사업을 모색해야 할 시점으로서 유선 망 인프라의 완성(인터넷 전용선, $\mathrm{ADSL}$ 등), 저렴한 $\mathrm{AP}$ 및 $\mathrm{NIC}$ (network interface card) 가격, ' 1 가구 $1 \mathrm{PC}$ '정책으로 인한 인터넷과 컴 퓨터산업 성장 효과 등은 유선 이후 “무선” 초 고속 인터넷 서비스의 도입을 촉진시킬 수 있 는 긍정적 요인으로 평가되었다.

따라서, 유선-무선 결합형 초고속 인터넷 서 비스는 '메가패스(ADSL)'의 뒤를 이어갈 신사 업으로서 '메가패스'가 라스트 원 마일(Last one mile ${ }^{2)}$ 에 초고속 유선 인터넷을 제공하고 있는 사업임에 착안하여, 라스트 원 마일(Last one mile)종단에 소형 무선기지국(AP)을 구축 함으로써 가정 내 혹은 구내 환경을 무선화 하 려는 개넘이다. 즉, 전세계적으로 검증된 기술표 준(IEEE 802.11b)인 무선 랜(wireless LAN)을

1) Enfortainment Service: Entertainment와 Information의 복합어로, 정보와 오락을 함께 제공한다는 의미.

2) 통신서비스를 이용하는 고객의 최대 행동반경을 일컬는 말로, 요즈음에는 고객 지향적인 의미로 '퍼스트 원 마일(first one mile)'이라 불리기도 한다. 
〈그림 1-2〉 초고속 인터넷 기반의 유무선 통합 서비스 개념도

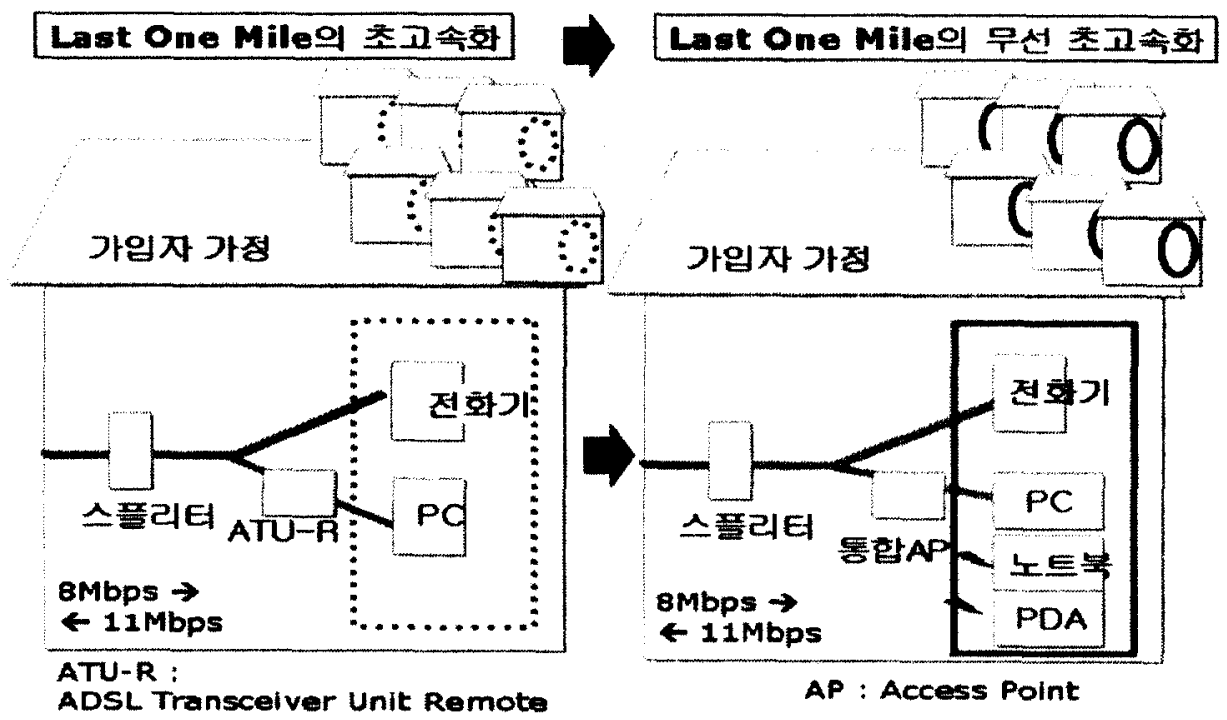

이용하여 노트북과 $\mathrm{PDA}$ 등 이동단말을 가진 고 은 '네스팟(NESPOT)'이라 이름 지어졌다. 네 객이 유선 초고속 인터넷과 거의 유사한 속도와 스팟은 네트워크(network) 과 핫스팟(hot spot) ${ }^{3}$ 품질로 인터넷을 이용할 수 있도록 하는 유선무선 결합형 초고속 인터넷 서비스인 것이다. 의 축약어이며, 핫스팟 및 가정 내에서 무선 LAN기반 네트워크를 이용하여 인터넷을 자유 롭게 이용한다는 것을 의미한다.

이를 상세히 설명하면 네스팟 서비스는 $\mathrm{xDSL}$."

II. 유무선통합 초고속 인터넷 서비스상품의 개발

\section{1 유무선통합 초고속 인터넷 서비스} 상품의 개요 및 타겟 분석

유무선 통합이라는 의미에서 신 서비스 상품
기업용 전용회선 ${ }^{51}$ 등 $\mathrm{KT}$ 의 네트워크를 가정. 기업/학교, 핫스팟(hot spot)까지 연결 한 후 (혹은 이미 포설되어 있는 경우 포함), 회선 종 단에 〈무선 초고속 인터넷 서비스〉 환경을 구 축하여 유선 인터넷 서비스가 가지고 있는 장 소적인 구속에서 벗어나 어디서든 자유롭게 초 고속 인터넷 서비스를 받을 수 있도록 한다는 것을 중심 테마로 하여 개발된 서비스이다. 이

3) 유동인구가 집중되어 모여있고. 인구의 이동이 빈번한 도심의 번화가를 핫스팟(Hot Spot)이라 부른다.

4) xDSL(extensible Digital Subscriber's Line) 인터넷 접속을 위한 초고속 접속망 기술로 ADSL과 VDSL이 상용화 되어 있다.

5) 인터넷서비스업체와 직접 연결한 통신회선으로. 희선을 전용으로 임대하역 사용하므로 전용희선 - 전용라인 또는 입대라 인(Leased Line)이라고도 한다. 
〈그림 2-1〉 네스팟 Brand Identity

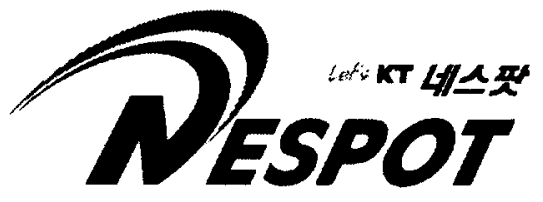

〈그림 2-2〉 네스팟(NESPOT) 서비스 모델

\begin{tabular}{|c|c|c|}
\hline (@ 가정 & $\begin{array}{l}\text { 기업/eㅏㄱㄱ } \\
\text { (@ Office) }\end{array}$ & $\begin{array}{c}\text { 굥굥장소 } \\
\text { (@ Public Zone) }\end{array}$ \\
\hline
\end{tabular}
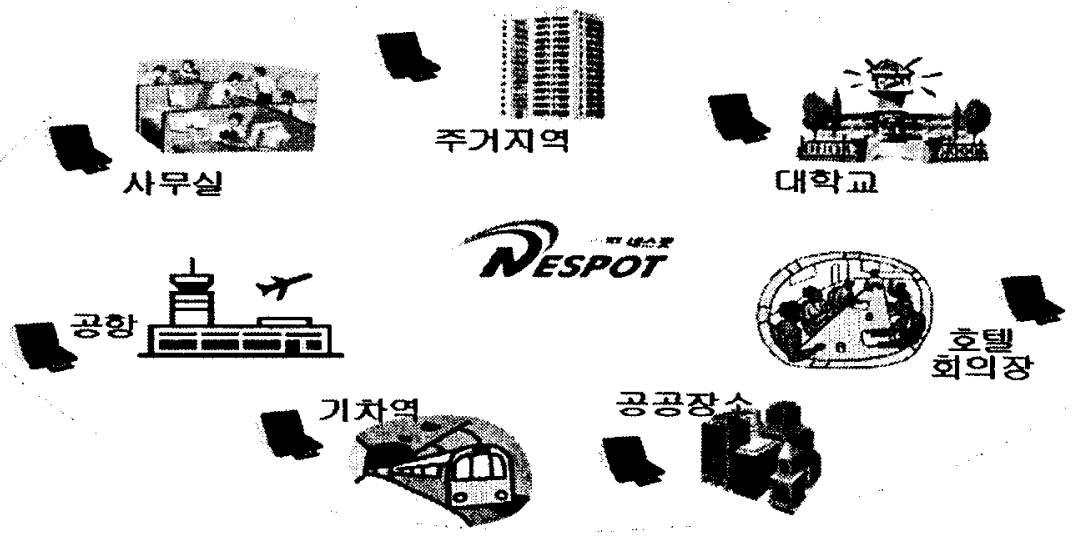

를 이해하기 쉽도록 도식화한 것이 〈그림 2-2〉 통하여 집을 비롯 전국의 네스팟 존에서 무선 이다.

그림에 나타난 바와 같이 네스팟 서비스를 제 공받을 수 있는 물리적 공간은 크게 가정, 기업 혹은 사무실, 핫스팟으로 나닌다. 즉 네스팟 가 입자는 상기와 같은 공간에서 개인의 고유한 ID와 비밀번호를 가지고 자유롭게 인터넷 망에 접속할 수 있게 된다.

네스팟의 시장은 크게 개인, 가정, 기업으로 세분화되는데 '개인고객'은 네스팟 ID를 구매하 여 전국의 네스팟 존에서 무선으로 인터넷을 이용할 수 있으며, '가정고객'은 네스팟 가입시 $\operatorname{ADSL}$ (혹은 VDSL) 1회선 및 무선 $1 \mathrm{ID}$ 를 제 공 받고 $\mathrm{AP}$ (Access Point)를 임대한다. 이를 인터넷을 이용할 수 있다. 기업고객의 경우는 (학교 포함), 기업주는 전용회선, 라우터, 인증 서버(필요 시), $\mathrm{VPN}$ 장치(필요 시) 및 다수의 $\mathrm{AP}$ 로 구성된 무선 랜 기반 인트라넷의 구축을 $\mathrm{KT}$ 에 의뢰하고 동시에 다량의 네스팟 ID를 구 매한다. 기업의 직원이나 방문 고객들은 빌딩 (혹은 학교)에서는 물론 회사 밖의 전국 네스 팟 존에서 자신의 $\mathrm{ID}$ 를 통해 무제한으로 무선 인터넷을 이용할 수 있게 된다.

2.2 네스팟의 경쟁환경 분석

공중 무선 랜을 이용한 유무선 통합서비스는 
인터넷 비즈니스의 새로운 수익모델을 찾고 있 는 통신 사업자들의 관심 대상이 되고 있다. 현 재의 시장구도는 $\mathrm{KT}\langle$ 네스팟〉, 하나로통신〈애니 웨이〉, 데이콤〈에어랜〉, SK Telecom〈WIN〉이 시장의 선점을 놓고 경쟁하는 양상을 보여주고 있는데, 유선통신 사업자인 KT, 하나로통신, 데 이콤은 가정가입자와 기업가입자를 대상으로 하는 독립적 브랜드 상품을 출시하고 있는 반 면, 이동통신 사업자인 $\mathrm{SK}$ 텔레콤은 공공장소 의 핫스팟 지역을 중심으로 독립상품이 아닌 기존 011 서비스의 보완재로 제공하고 있다. 이 처럽 국내 모든 통신 사업자는 자사의 핵심 사 업 또는 미래 사업에 유리하도록 공중 무선 랜 서비스를 서로 다른 비즈니스 모델로 차별화하 고 있다.

네스팟은 우선 기존의 유선 초고속 인터넷 서 비스에 비해 장소적 접근이라는 측면에서 경쟁 우위 적 요소를 가지고 있다. 즉 유선 초고속 인터넷 서비스는 가정이나 사무실 등 데스크 탑 컴퓨터가 설치된 고정된 공간에서만 이용할 수 있었지만. 네스팟은 가정뿐만 아니라 사무
실, 핫스팟이 설치된 곳이라면 공공장소에서도 자유로이 이용할 수 있다.

물론 이동통신(CDMA) 무선인터넷이 공간적 인 측면에서만 보면 네스팟보다 더 나은 경쟁 우위요소를 가지고 있음은 부인할 수 없다. 그 러나 이동통신 무선인터넷은 요금부담이 큰 반 면, 네스팟은 월정액으로 무제한 초고속 인터넷 서비스를 받을 수 있도록 정액제 서비스를 기 본적으로 선택하고 있기 때문에 비용면에서 우 월적인 경쟁우위요소를 가지고 있다.

이처럼 네스팟은 장소적 구속에서 비교적 자 유롭고 매우 저렴한 비용으로 유선과 같은 초 고속 인터넷의 속도를 무선환경에서 누릴 수 있다는 장점이 있는 반면, 최대 출력 제한이라 는 정부의 무선 랜 주파수 정책 특성상 모든 장소에서 이용할 수 있는 것이 아니라 $\mathrm{KT}$ 의 전용선 및 네트워크 인프라가 설치되었거나 설 치될 수 있는 지역에만 국지적으로 제공된다는 한계가 있다. 따라서 <무선 초고속 인터넷 서비 스>에 대한 수요가 많은 장소를 선택하여 네스 팟(NEPSOT)을 구축해야 하는 “선택"과 “집

〈그림 2-3〉 SWOT 분석율 이용한 네스팟의 경쟁환경 분석

\begin{tabular}{|c|c|}
\hline 강점 & 약점 \\
\hline $\begin{array}{l}\text { - 기존망 활용으로 저렴한 망투자비 } \\
\text { - 11Mbps의 고속무선 인터넷 } \\
\text { - 월정액제 무제한 시용 } \\
\text { - 공공장소(네스팟존)에서 사용 }\end{array}$ & $\begin{array}{l}\text { - 이동통신 대비 제한된 이동성 } \\
\text { (네스맛 구축존에서만 가능) } \\
\text { - 노트묵.PDA의 고가격 }\end{array}$ \\
\hline 기회 & 위협 \\
\hline $\begin{array}{l}\text { - 천만 초고속 인디넷 가입자의 이동 인디넷 } \\
\text { 에 대한 요구 } \\
\text { - } 4 \text { 천만 이동통신 가입자의 저렴한 우선 } \\
\text { 인터넷 } 8 \text { 구 } \\
\text { - 노트북.POA 대중화 예상 }\end{array}$ & $\begin{array}{l}\text { - 경쟁업체의 Hot Spot 존 선점 } \\
\text { - 가정용 무선랜 장비 대중화 }\end{array}$ \\
\hline
\end{tabular}


중” 전랴이 효과적일 것이라 판단되었다.

일반적으로 초고속 인터넷 사용 습성을 볼 때, 인터넷을 자주 이용하는 장소는 (1) 여유시 간을 가질 수 있는 가정, (2) 업무 장소인 회사 및 학교 (3) 사람을 기다린다거나 즐기며 휴식 할 수 있는 카페. 극장. 대형 콤플렉스 등의 핫 스팟으로 분류된다. 따라서 네스팟 서비스 가능 환경은 가정, 기업/화교, 핫스팟을 중심으로 〈초고속 무선 인터넷 서비스〉환경을 집중적으 로 구축하여야 한다.

\section{II. 네스팟의 캐즘(Chasm) 발생}

앞서 살펴본 바와 같이 유선 초고속인터넷 서 비스 시장의 포화상태를 극복하고 새로운 수익 원을 창출하기 위해 출시된 네스팟은 여러 가 지 장점에도 불구하고 신규시장을 형성해가는 과정에서 현실적으로 많은 문제점에 맞닥뜨려 야 했다.
특히 첨단 기술 상품 서비스는 소비자에게 인 지시키고 관심을 불러 일으키는 초기수용단계 를 거쳐 이를 대중화하는 과정에서 많은 난관 에 부딪치게 되는데, 이러한 난관들을 극복하기 위한 새로운 마케팅 전랴이 필요하게 된 것이다.

\section{1 캐즘의 개념}

일반적으로 상품은 대중화 되기까지, 도입 기. 성장기. 성숙기, 쇠퇴기라는 '제품수명주기 (product life cycle)'를 가지게 된다. 그런데 첨 단 기술 기반의 서비스의 경우〈그립 3-1〉과 같이 제품 수명주기의 단계별로 연속되지 않은 단절이 존재하게 된다.

첨단 기술 기반의 제품들이 제품 수명 주기에 서 단절을 격게 되는 실제 사례는 다음의 〈표 3-1〉 과 같다. 이 중, 제품이 시장에 출시되어 초기 시장이 형성되었으나, 성장기로 진입하지 못하 고 있는 상태를 캐즘(chasm)이라고 한다. 즉, 주류시장으로 진입하지 못하여 판매가 정체되 고, 제품이 조기 수용자 시장에 계속 공급되기

〈그림 3-1〉 첨단 제품의 제품 수명주기 및 캐즘

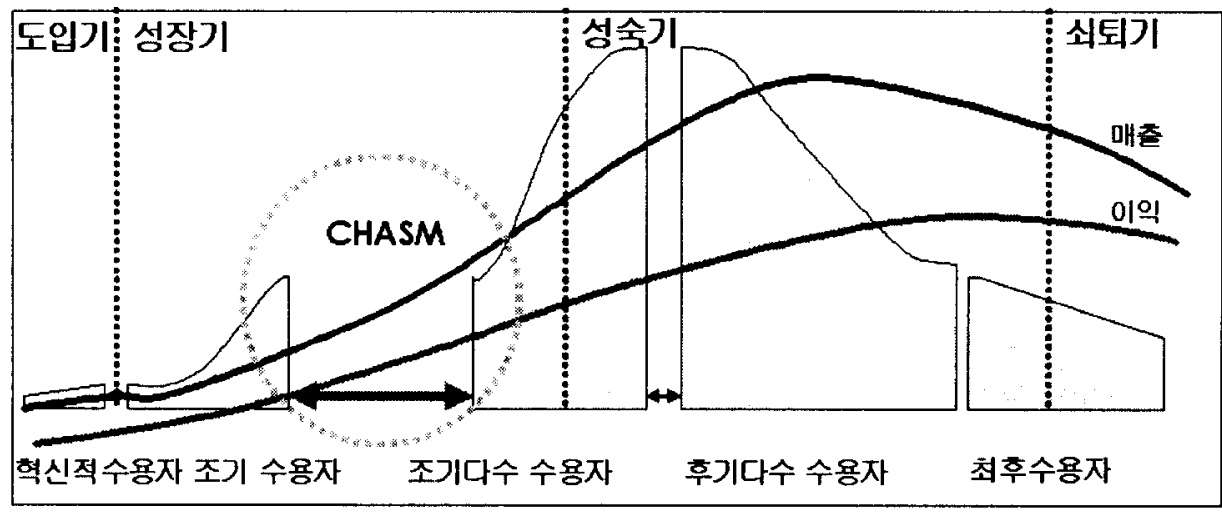

출처: 제프리 A.무어(2002), 캐즘 마케팅, p.40의 내용을 재구성 
〈표 3-1〉 첨단기술 제품의 단절의 유형과 뿍징

\begin{tabular}{|c|c|c|}
\hline & 사 례 & 폭 징 \\
\hline $\begin{array}{l}\text { 혁신적수용자와 } \\
\text { 조기수용자 } \\
\text { 사이의 단절 }\end{array}$ & $\begin{array}{l}\text { 에스페란토어 } \\
\text { 신경망 } \mathrm{S} / \mathrm{W} \\
\text { 컴퓨터화상회의 }\end{array}$ & $\begin{array}{l}\text { - 홍미롭고 편한 기술로 혁신적 수용자의 관심 유도에는 } \\
\text { 성공 } \\
\text { - 새로운 제품의 능력과 가치를 나타낼 수 있는 설득력 } \\
\text { 있는 응용분야를 못 찾음 } \\
\text { - 연구개발품으로 그침 }\end{array}$ \\
\hline $\begin{array}{l}\text { 조기수용자와 } \\
\text { 조기 다수 수용자 } \\
\text { 사이의 단절 }\end{array}$ & $\begin{array}{l}\text { 인공지능 } \\
\text { 이더넷 } \\
\text { 케이블모뎀 } \\
\text { 전자서명 } \\
\text { 음성인식 } \\
\text { PC호환 TV } \\
\text { 전자책 } \\
\text { 데이터마이님 기술 } \\
\text { 인터넷 화상 전화 }\end{array}$ & $\begin{array}{l}\text { - 가장 중요한 캐즘(단절) } \\
\text { - 초기시장에서 주류시장으로 전환하는 가장 극적인 대변환 } \\
\text { 단계 } \\
\text { - 제품을 대중적으로 수용하기에는 위헙요소가 감지되며, } \\
\text { 주류시장 진입을 위한 마케팅 노력이 효력을 발회하지 } \\
\text { 못하여 판매는 정체됩 } \\
\text { - 제품이 조기 수용자 시장에 계속 공급되기는 하지만 } \\
\text { 대량판매의 주류시장으로 이어지지 않음. }\end{array}$ \\
\hline $\begin{array}{l}\text { 조기다수수용자와 } \\
\text { 최후 수용자 } \\
\text { 사이의 단절 }\end{array}$ & $\begin{array}{l}\mathrm{VCR} \text { 의 예약녹화기능 } \\
\text { 첨단 사무용 복사시스템 } \\
\text { 전화회의 }\end{array}$ & $\begin{array}{l}\text { - 시장이 이미 잘 개발되어 있고 기술제품도 주류시장으로 } \\
\text { 흡수되어 있음. } \\
\text { - 게으른 후기다수 사용자가 제품을 쉽고 능숙하게 이용 } \\
\text { 할 수 있도록 하는데 실패하여 대중화/일반화에는 실패 }\end{array}$ \\
\hline
\end{tabular}

출처: 제프리 A.무어(2002), 캐즘 마케팅, pp.40 48의 내용을 재구성

는 하지만 대량판매 되는 주류시장으로 이어지 지 않고 있는 상태를 뜻한다.

첨단 기술 상품의 마케팅 활동에는 기술, 제 품, 시장, 기업 이 네 가지 중요 요소들이 있으 며, 제품이 기술 수용 주기를 따라 변하면서 고 객에게 가장 중요한 가치도 달라지게 된다. 기 술 애호가와 선구자들이 의사 결정을 주도하는 초기 시장의 중요한 가치는〈기술과 제품〉이다. 그러나 캐즘을 뛰어넘어 실용주의자와 보수주 의자가 의사결정을 주도하는 주류시장에서는 중요한 가치가 〈시장과 기업〉이 된다. 따라서 캐즘을 뛰어넘는다는 것은 제품중심의 가치에 서 시장중심의 가치로 이행하는 것을 뜻한다.
초기시장에는 제품 자체의 기술적 혁신성에 관 심이 많은 전문가들이 주류를 이루며, 주류시장 에는 제품 성능 보다는 표준이 될 정도의 제품 의 안정성에 더 많은 관심을 보이는 일반인들 이 주류를 이룬다.

\section{2 캐즘의 원인 규명}

네스팟의 경우는 조기 수용자(early adopter) 들에게 점차 확산 되고 있지만, 본격적인 대중 화를 위한 성장기로의 진입은 지체되고 있다 할 수 있다. 일반적으로〈혁신적 신제품〉은 경 쟁 제품이 없고, 고객이 새로운 카테고리의 제 
품을 모르거나 다른 카테고리에서 옮겨와야 하 기 때문에 고객 저항이 높다(Sheth 1981). 이 러한 측면에서 볼 때, 무선 초고속 인터넷이라 는 첨단 기술로 태동된 네스팟은 고객저항을 동반하는 캐즘(CHASM)에 직면한 것으로 판 단되었으며, 따라서 마케팅 전략의 전환이 필요 하게 되었다.

\subsection{1 첨단기술 신 상품 개넘에 대한 이해도 부족}

유무선통합 초고속 인터넷 서비스인 네스팟 상품 개념에 대한 이해가 부족하다는 것이 큰 문제로 제기되었다. 무선LAN이란 기술이 개발 된지는 오래되었지만 실제 보편화 되기 시작한 것은 얼마되지 않아 일반 사용자들의 실 생활 에 친근하게 활용하기에는 다소 거리가 있는 상품 개념이다.

2002년 상반기의 네스팟 마케팅의 타겟 고객 은 주로 IT 전문가들로 구성된 기술 애호가나 조기 수용자였으며, 첨단 기술이 제품화되었다 는 혁신적 이미지가 마케팅 개념으로 사용되어 아직은 국내에 생소한 무선 랜을 공중(public) 형 서비스로 제공한다는 첨단 기술력을 강조하 였다. 또한 기존의 이동통신을 이용한 저속의 무선인터넷과는 차별화된 속도와 경제성을 강 조하고, 서비스의 고급화에 맞추어 상대적으로 높은 서비스 요금을 설정하였다. 상반기의 마케 팅 활동 방향은 초기 시장 진입 및 안착을 위 한 제품 중심적 마케팅이었다.

그러나 이러한 마케팅 활동은 그 동안 IT 관 련자 등 조기 수용자(early adopter)들이 네스 팟을 첨단 기술 서비스로서 관심 갖게 하는데
그쳤으며, 실제 구매로까지 연계되기 위해서는 상품의 가치에 대한 확신을 더 심어주는 것이 필요하다고 판단되었다. 네스팟을 단순히 호기 심을 갖는 신기한 상품이라는 개념에서 벗어나 대중적이고 생활을 편리하게 해주는 생활 필수 품으로 보편화하기 위한 기폭제가 절실히 필요 한 것이다.

2002년 후반기의 네스팟 마케팅은 초기시장보 다는 본격적인 주류시장에 눈을 돌린 것으로 판단 되며, 주류시장은 초기시장과는 전혀 반대 의 성격을 가지고 있다. 주류시장의 고객들은 초기 시장의 조기수용자(early adopter)들과는 다른 톡성을 가지고 있으므로 이에 맞는 마케 팅 전략의 개발이 필요하다.

\section{2 .2 노트북, $\mathrm{PDA}$ 시장에의 의존성 문제}

실제 무선 랜을 사용할 니즈를 느끼는 고객 군은 우선적으로 네스팟 서비스가 가능한 단말 을 보유하고 있어야 한다. 즉, 가구 당 $\mathrm{PC}$ 의 개수가 2개를 넘는 다거나. 네트워킹이 가능한 노트북 혹은 $\mathrm{PDA}$ 를 가지고 있어야 한다. 이러 한 잠재고객 군이 존재하는 것은 명확하지만 각각 시장에서의 노출도가 매우 낮기 때문에 마케팅상의 어려움이 상존하게 되는 것이다. 또 한 네스팟은 이러한 노트북이나 PDA시장의 규 모가 커질수록 주류 시장 형성이 용이한, 즉 타 시장에의 의존적 성격을 가지고 있다는 점에서 구조적인 문제점을 가지고 있다.

그러나 PC교체 주기 도래, 노트북 PC 가격 하락, 무선랜 원천 탑재 노트북 양산, PDA보 급 증대 등으로 네스팟 사업의 단말 환경 측 면에서 유리하게 전개될 것으로 전망되므로 
이를 적극 활용하는 것이 바랍직하다고 판단 된다.

\section{2 .3 장소적 제한의 문제}

네스팟이 기존 유선 초고속 인터넷 서비스에 비하여 월등히 장소적 구속에서 벗어날 수 있 는 제품임에는 틀립없으나. 서비스 모델의 특성 상 핫스팟 지역 외에서는 사용할 수 없다는 점 에서는 여전히 장소적 제한이 따를 수밖에 없 다는 한계를 내재하고 있음도 사실이다. 따라서 '언제 어디서나 자유롭게 초고속 인터넷 서비스 를 활용케 한다는 특징을 구현하기 위해서 여 러 가지 방안이 모색되어져야 했다. 소비자들이 궁극적으로 원하는 서비스는 장소적 제한에서 완전히 자유롭고 더불어 저렴한 비용으로 초고 속 인터넷을 할 수 있는 것이기 때문이다. 그리 하여 네스팟을 일반대중화함에 있어서 장소적
제한의 문제는 중요한 관건중의 하나로 여겨지 게 되었다.

\section{3 네스팟의 마케팅 전략 전환}

2002년 상반기의 네스팟 마케팅의 타겟 고객 은 주로 IT 전문가들로 구성된 기술 애호가나 조기 수용자였으며, 첨단 기술이 제품화되었다 는 혁신적 이미지가 마케팅 개넘으로 사용되 었다. 아직은 국내에 생소한 무선랜을 공중 (public)형 서비스로 제공한다는 첨단 기술력을 강조하였다. 또한 기존의 이동통신을 이용한 저 속의 무선인터넷과는 차별화된 속도와 경제성을 강조하고 고급화 서비스의 개념에 맞추어 상대 적으로 높은 서비스 요금을 설정하였다. 이처럼 상반기의 마케팅 활동 방향은 초기 시장 진입 및 안착을 위한 제품 중심적 마케팅이었다.

그러나 이러한 마케팅 활동은 그 동안 IT 관

〈그림 3-2〉 네스팟의 캐즘 분석과 마케팅 전략의 전환

- 케품 개념의 임인인 어려워 첨단기술제품
에 대한 이해도가 부족함.
- 초기수용 단계에서 주류시장으로 진
입하지 못 하는 문제 발샘
- 노트북/PDA 에 대한의 의존도가
높음
- 제한적 사용 장소의 문제

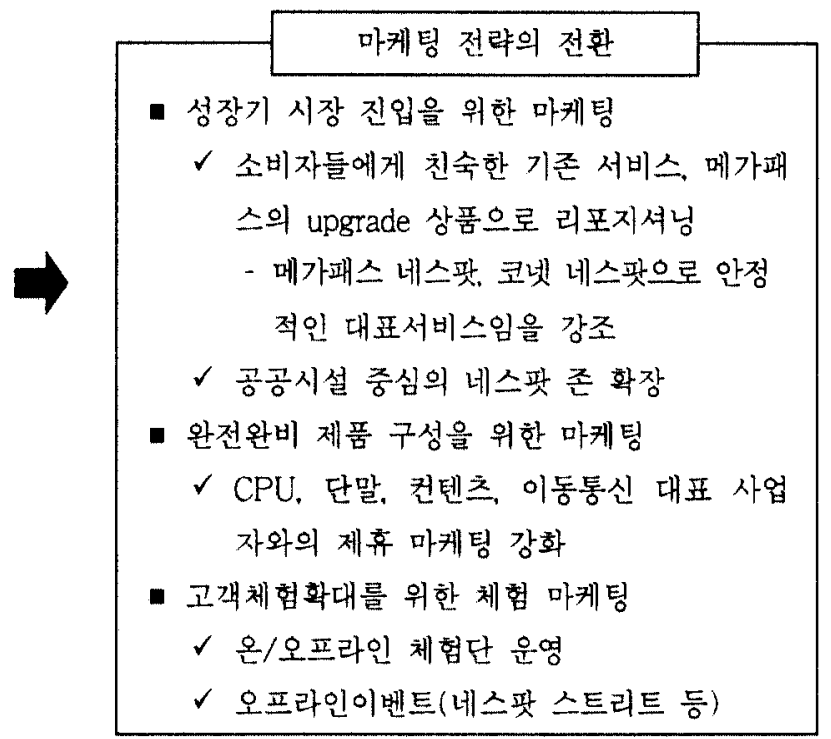


련자 등 조기 수용자(early adopter)들이 네스팟 을 첨단 기술 서비스로서 관심 갖게 하는데 그 쳤다고 판단되며, 실제 구매로까지 연계되기 위 해서는 상품의 가치에 대한 확신을 더 심어주는 것이 필요하다. 네스팟을 단순히 호기심을 갖는 신기한 상품이라는 개념에서 벗어나 대중적이고 생활을 편리하게 해주는 생활 필수품으로 보편 화하기 위한 기폭제가 필요하다고 하겠다.

2002년 후반기의 네스팟 마케팅은 시장 도입 기를 벗어나 성장기로 본격 진입하는데 성공한 것으로 판단 된다. 주류시장은 초기시장과는 전 혀 반대의 성격을 가지고 있다. 주류시장의 고 객들은 제품의 품질과 가치를 꼼꼼히 따져보고 구매하는 실용주의자 및 보수주의자로 구성되 어 있기 때문에, 그들은 제품의 혁신성이나 첨 단기술보다는 그 제품이 나에게 가져 다 주는 실제적 가치를 알고 싶어한다. 따라서 이러한 고객들에게 소구할 수 있는 마케팅 전략의 수 립이 요청되었다. 요컨대, 주류 시장으로의 진
입을 방해하는 여러 현실적인 문제점에 직면하 게 되면서 이러한 문제점들의 원인을 분석하고. 네스팟의 마케팅 전략을 전환하는 것이 불가피 하게 되었다.

\section{IV. 캐즘 극복과 성장기 진입을 위한 마케팅 전략}

\section{1 타겟의 재설정과 리포지셔닝}

캐즘을 극복하고 성장기 시장으로 진입하기 위해서, 네스팟이 가장 처음 해결해야 할 도전 은 타겟 고객의 재설정이었다. 즉, 첨단기술상 품에 우호적인 조기 수용자들로부터 신기술 서 비스에 대해 까다로우며, 십고 안전한 서비스만 을 선호하는 실용주의자들로 타겟을 재설정 해 야 하는 것이 캐즘 극복 및 주류시장의 확산에

〈표 4-1〉 신제품 확산단계에 따른 고객 유형 및 특성

\begin{tabular}{|c|c|}
\hline 고개유형 & 특 \\
\hline $\begin{array}{l}\text { 혁신적 수용자 } \\
\quad \& \\
\text { 조기 수용자 }\end{array}$ & $\begin{array}{l}\text { 신제품이 나오면 남보다 먼저 사는 편 } \\
\text { 남들보다 앞서간다는 느낌을 주기 위해 노력 } \\
\text { 새로운 기술이 적용된 첨단 제품 구매 } \\
\text { 특별히 계획에 없던 물건도 눈에 띄면 사는 경우가 많은 편 }\end{array}$ \\
\hline \multirow{2}{*}{$\begin{array}{l}\text { 조기 다수 } \\
\text { 수용자 }\end{array}$} & $\begin{array}{l}\text { 구매하는 제품은 자신의 스타일 또는 이미지를 상징 } \\
\text { 가젹이 비싸더라도 디자인 중시 구매 } \\
\text { 제품 선택 시 브랜드 이미지 중시 }\end{array}$ \\
\hline & $\begin{array}{l}\text { 제품에 대한 판단에 대해 주위에 권유하거나 말리는 편(big mouth) } \\
\text { 저럼하게 구입하기 위해 여러 정보를 꼼꼼히 비교 } \\
\text { 인터넷이 생활의 일부. 정보원으로 활용 }\end{array}$ \\
\hline $\begin{array}{l}\text { 후기다수 수용자 및 } \\
\text { 최종 수용자 }\end{array}$ & $\begin{array}{l}\text { 제품 구입시 단순한 기능 선호, 특정 브랜드 반복 구매 } \\
\text { 제품 구입시 가격 중시 }\end{array}$ \\
\hline
\end{tabular}


있어서 가장 중요한 부분이기 때문이다.

이를 위해 네스팟은 우선 제품에 대한 포지셔 닝 변경을 시도했다. 〈메가패스 ADSL의 업그 레이드 무선화〉로 정하고, 이전의 무선 초고속 서비스 측면의 강조에서 탈피하여〈초고속 유 선의 무선화>란 개념으로 고객이 쉽게 이해 수 있도록 리포지셔닝 하였다. 또한 타겟 고객을 인터넷 다량사용자 매니아 중심에서 무선 이용 을 원하는 메가패스 가입자 및 타 경쟁 상품
가입자로 확대시키고자 하였다. 즉 인터넷 매니 아들로 구성된〈전자/IT제품 구입시 첨단기술 을 적용한 상품을 구입하고, 기본기능 및 부가 기능도 자주 사용하는 인터넷 매니아 집단에 서 확대하여〈평소 물건 구입시 실용/경제성을 따져보며, 여러 정보와 상품들을 끔끔히 살펴보 고 비교하는 집단〉 및 〈가격이 다소 비싸도 유 명 브랜드의 제품을 주로 구입하고, 제품구입시 무엇보다 디자인 및 제품 브랜드를 중요하게

〈표 4-2〉 캐즘 극복을 위한 마케팅 전략의 변화

\begin{tabular}{|c|c|c|}
\hline & 캐즘 이전(2002 상반기) & 캐즘 이후(2002 하반기 - 현재 ) \\
\hline 목표 & 초기 시장 개발(시장도입기) & 주류시장 개발(성장기 진입) \\
\hline 포지셔닝 & 초고속 무선 인터넷 & $\begin{array}{l}\text { 오초고속 메가패스의 무선화 } \\
\text { 이이업내 전용선의 무선화 }\end{array}$ \\
\hline 표적고객 & $\begin{array}{l}\text { 윽혁신적 수용자 } \\
\text { 오노트북, PDA 등 이동단말을 보유한 } \\
\text { 개인, 가정. 기업 }\end{array}$ & $\begin{array}{l}\text { 조기 수용자 및 조기다수 수용자 } \\
0 \text { 메가패스 가입자 } \\
0 \text { 1가구 2PC 보유 가정 } \\
0 \text { 기업 혹은 대학교 } \\
0 \text { 노트북, PDA 보유자 혹은 구매 의향자 }\end{array}$ \\
\hline $\begin{array}{l}\text { 커뮤니케이션 } \\
\text { 소구점 }\end{array}$ & 초고속 무선 인터넷임을 강조 & 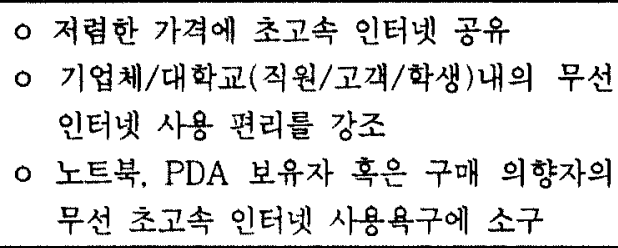 \\
\hline 경쟁 & \multicolumn{2}{|c|}{ 데이콤, 하나로통신. SKT 등 공중 무선랜 사업자 } \\
\hline $\begin{array}{l}\text { 완전완비제품 } \\
\text { (Whole Product) }\end{array}$ & $\begin{array}{l}\text { 번화가 네스팟 존 구축 } \\
\text { 무선랜카드 보급 대중화 }\end{array}$ & $\begin{array}{l}\text { 관련 기업과의 제휴마케팅을 통한 무선 인터넷 } \\
\text { 활성화 공동 유도 }\end{array}$ \\
\hline $\begin{array}{c}\text { 파트너와의 } \\
\text { 제휴 }\end{array}$ & & $\begin{array}{l}\text { - 이동통신 업체와의 제휴 } \\
\text { - CPU 업체와의 공동 마케팅 } \\
\text { - 네스팟 용 단말 제조업체와의 제휴 } \\
\text { - 컨텐츠 업체와의 제휴 } \\
\text { - 네스팟존확보용 기업/지자체 제휴 }\end{array}$ \\
\hline 유퉁 & 지사(구 전화국) & $\begin{array}{l}\text { - } \mathrm{KT} \text { 지사외의 외부 유통망 확대 } \\
\text { - RM요원의 기업 대상 영업 실시 }\end{array}$ \\
\hline 가격 & 월6만원(초고속 요금 포함) & - Plus 1만원(초고속인터넷 별도) \\
\hline
\end{tabular}


고려하는 집단)과 같은 조기 다수 수용자 집단 을 대상으로 확대하고 이들을 타겟으로 하는 마케팅 전략을 수립하였다.

제품 포지셔닝의 변화에 따라 네스팟 브랜드 체계 및 상품 구조 역시 메가패스 서비스 기반 을 적극 활용할 수 있도록 변경하였다. 2002년 상반기의 〈네스팟〉 단독 브랜드를 이용한 고객 과의 커뮤니케이션은 대고객 인지도 측면에서 취약하므로, $\mathrm{KT}$ 가 이미 대형의 브랜드 파워를 가지고 있는 '메가패스'에 '네스팟'을 연결시켜 주류시장의 고객들에게 쉽게 인식될 수 있도록 하였다. 이에 따라 기존의 상품명인 〈네스팟 가 정용〉은 〈메가패스 네스팟〉으로 브랜드 체계가 변경되었으며, 동시에 주류시장의 진입을 위하 여 메가패스 유선 서비스에 가입한 가입자들의 경우 월 1 만원의 무선 ID 요금을 추가하면 가 정에서도 네스팟 서비스가 가능하도록 전체적 요금구조도 변경하였다.

매체를 활용한 고객 커뮤니케이션은 컴퓨터가 2대 이상인 가정을 대상으로 하는 저렴하고도 편리한 메가패스의 부가 서비스가 출시되었다 는 메시지를 전달하고자 하였으며. 1 가구 $2 \mathrm{PC}$ 및 노트북 보유 세대를 타겟으로 $\mathrm{KT}$ 네스팟을 사용하는 가정과 사용하지 않는 가정을 대비시 키는 인지 광고를 실시하였다.

\section{2 완전완비제품 구성을 위한 제휴 마케팅의 확대}

\subsection{1 완전완비제품의 개념}

정보통신 서비스는 네트워크-단말-서비스 특 성이 잘 융합 되어 고객에게 제공되어야 단일
상품으로서의 완전한 모습을 갖추게 된다. 이를 첨단기술 마케팅에서는 '완전완비제품(the whole product)'이란 용어로 표현하고 있다(무어 2002).

완전완비제품이란 '제품을 구성하는 가장 핵 심적인 개념만이 아니라 잠재적 제품개념까지 를 포함한 광범위한 제품 개념’을 의미한다. 주 류시장의 대다수를 차지하는 조기다수 수용자 와 최후 수용자들은 실용주의자들로서 제품을 구입하자마자 별도의 지식 없이도 십게 설치하 여 사용하고자 하며, 어디서나 십게 구할 수 있 고, 기술 $\mathrm{A} / \mathrm{S}$ 등의 고객지원이 완벽한 완전완 비제품을 선호한다. 따라서 캐즘을 뛰어넘어 주 류시장에 안착하기 위해서 제품은 완전완비제 품의 특성을 가져야 한다.

\section{2 .2 완전완비제품 구성을 위한 제휴 마케팅 전략의 활용}

한 가정이 네스팟에 가입했을 경우, KT가 기 본으로 제공하는 통상제품은 (1) KT에서 가정 댁내까지의 유선 초고속 인터넷 메가패스 1 회 선 (2) 유무선 통합 모뎀 장치(유선모뎀 + 무 선 Access Point) (3) 초고속 인터넷 접속용 유선 ID 1개, 무선 ID 1개로 이루어 지며, 이와 별도로 고객의 판단에 따라서 무선랜 카드 ( $\mathrm{PDA} /$ 노트북용), 이동단말(노트북/PDA)등의 단말을 함께 구입할 수 있게 되어있다.

완전완비제품을 위한 2002년도 네스팟 활동은 크게 '서비스 가능 지역 확대를 위한 네스팟 존 확장, '접속 품질을 향상시키기 위한 시스템 안 정화', '유관 사업자와의 제휴 마케팅'으로 대표 된다. 주목할 것은 $\mathrm{KT}$ 자체적으로는 해결할 수 없는 완전완비제품 구성의 주요 부문 해결을 
〈그림 4-1〉 네스팟의 완전완비제품 모델 적용

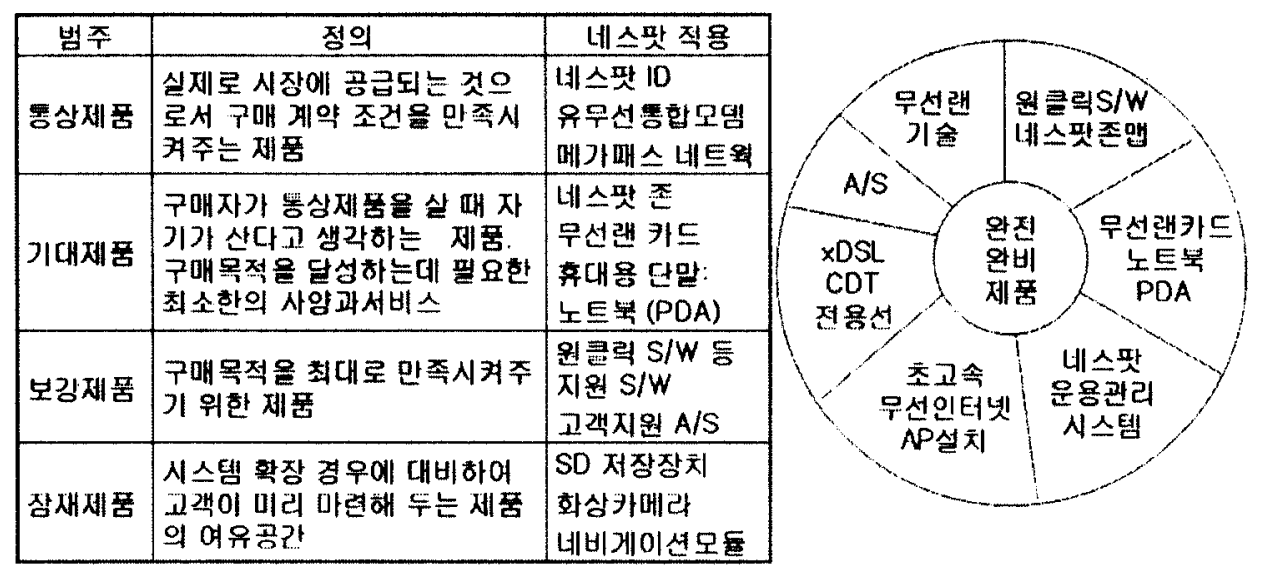

위해 실시된 제휴 마케팅이다.

$\mathrm{KT}$ 의 제휴 마케팅은 크게 두 가지 유형으로 구분해 볼 수 있는데 그 첫째는 무선랜 관련 유관 사업체인 $\mathrm{CPU}$ 제조업체 $\mathrm{A}$ 사, 노트북 제 조업체인 $\mathrm{B}$ 사, 컴퓨터 운영체제 사업자인 $\mathrm{C}$ 사. 인터넷 컨텐츠 사업자인 $\mathrm{D}$ 사 등과의 전략적 제
휴를 통한 공동 마케팅 활동을 들 수 있다. 네 스팟은 노트북. $\mathrm{PDA}$ 등 고성능/고가의 휴대 단말을 사용하는 초고속 무선 인터넷 시장이라 는 미성숙 시장을 대상으로 하므로, 네트웍 사 업자인 KT의 단일 주도 능력만으로는 한계가 있다. KT는 이러한 환경 하에서 〈무선 초고속

〈그림 4-2〉 공동 마케팅 제휴 개념도

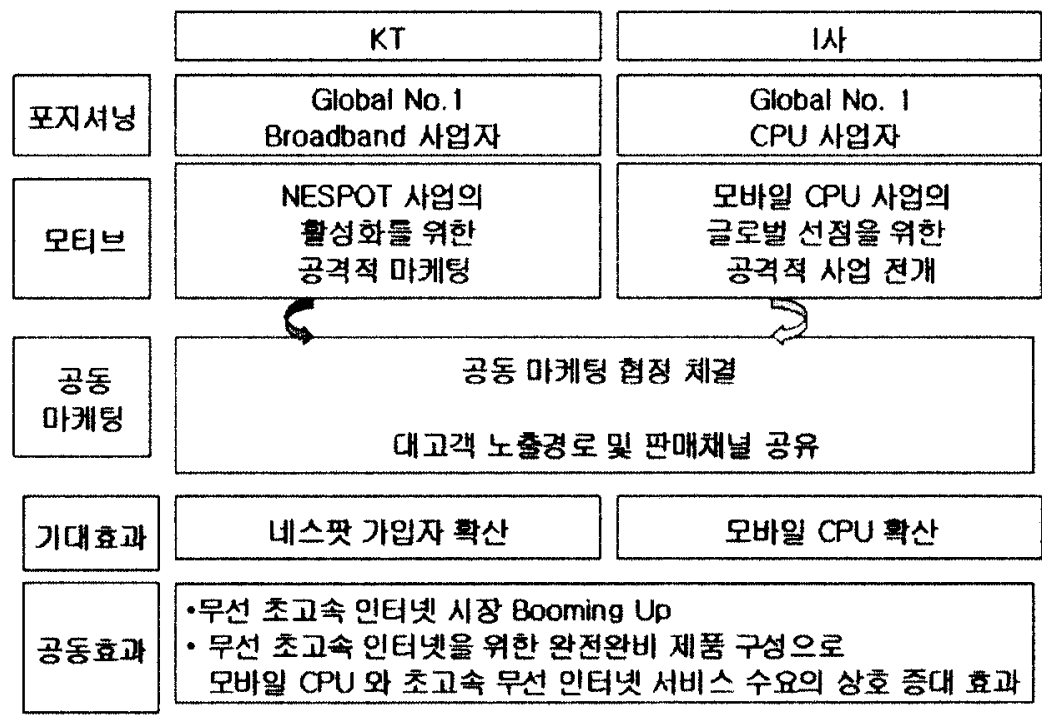

출처: KT 네스팟과 I사와의 전랴적 제휴 재정리(2002.7) 
〈그림 4-3〉 완전완비제품 모델을 위한 네스팟 스윙의 제품 포지셔닝과 광고

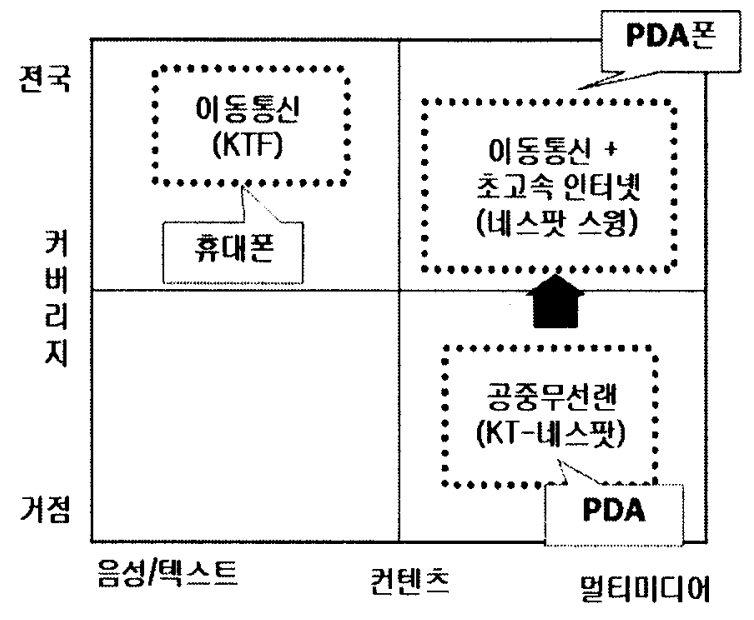

출처: 네스팟 스윙(Swing) 광고 자료(2002) 및 포지션잉

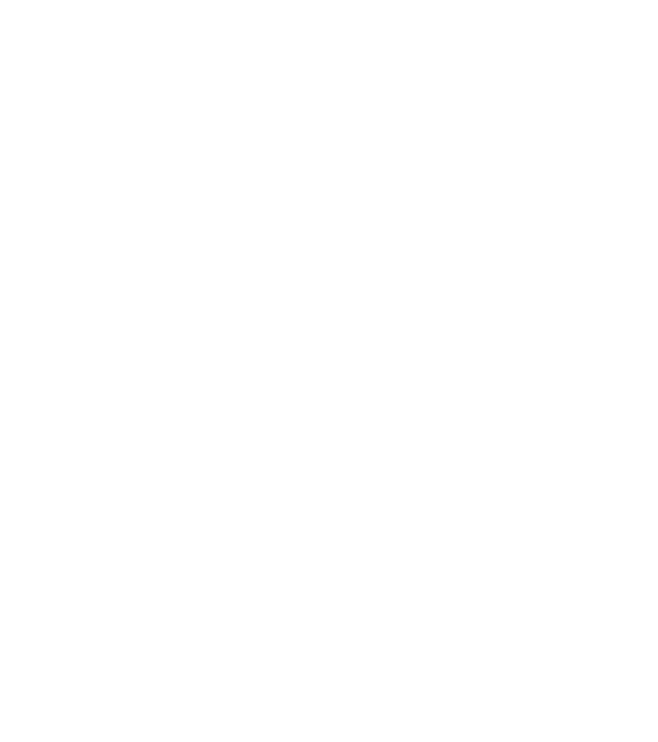

이렇게 하여 만들어진 네스팟 스윙(NESPOT Swing) 서비스는 가입 고객이 네스팟 존에서 는 네스팟 망을, 그 외의 지역에서는 이동통신 사의 CDMA-1X 망을 이용할 수 있음으로써, 고객이 언제 어디서든 끊임없이 인터넷에 연결 될 수 있도록 하였다. 위의 그림은 네스팟 스윙 을 위한 런칭 광고이다.

\section{3 고객체험 확대를 위한 체험 마케팅의 활용}

전통적 마케팅이 제품의 특징과 편익을 중시 하고 고객이 구매하도록 설득하는 데에 중점을 둔 것에 비해, 구입과정이나 구매 후의 소비자 경험을 중요시하고, 고객의 감각과 감성, 체험 을 적극 활용하는 마케팅을 체험 마케팅이라 한다(박성연 외 공역 2002). 수 있는 이동통신사의 네트웍과 결합하는 복합 서비스를 기희, 고객에게 제공하고자 하였다. 


\subsection{1 네스팟의 체험 마케팅 전략}

네스팟의 실체를 잘 모르는 잠재 고객들에게 직접 체헙해볼 수 있는 기회를 적극 제공함으 로써 네스팟을 재미있고 효용성 있는 서비스로 느낄 수 있도록 하기 위해 체헙 마케팅을 적극 적으로 전개하였다. 이벤트 형식을 빌어 진행된 체헙 프로그램들을 지속적으로 전개함으로써 네스팟은 소비자가 생활하고, 일하고, 노는 곳 에서 감성적이고 기억에 남는 연결고리를 만들 어낼 수 있었다.

네스팟은 제휴 파트너 사들과 합께 잠재고객 집단인 대학생 및 18 30대 집단의 관심을 유 발시키기 위해, 인터넷 대량사용자인 이들을 대 상으로〈네스팟 오딧세이(NESPOT Odyssey)〉 라는 고객 체험 마케팅 프로그램을 실시하였다.

오객체험 프로그램을 〈NESPOT 오딧세 이> 개넘으로 일관성 있게 진행한다.

으대량 사용자를 중심으로 유익한 이벤트 운 영, 재미있고 효용성 있는 서비스로 각인 토록 한다.

어서비스 활용 및 신규 아이디어 도출, 망 안정성 및 단말 적용성 검증에 활용한다.

대학생 집단을 대상으로 5 월의 대학축제와 연 계된〈네스팟 오딧세이 1편, 캠퍼스 열전〉, 6월 9 월까지의 대학생과 PDA 대량사용자를 중심으 로 운영된 〈PDA 체험단-네스팟 오딧세이 2편, 네스팟 프리모〉, 11월 - 12 월에 운영된〈네스팟센스큐와 함께 하는 무선랜 체헙단>, 11 월의 서 울시내 주요 핫스팟 지역에서 동시에 열린 〈네 스팟 스트리트 거리 축제> 등은 그 네스팟이 운
영한 체험 마케팅의 대표적인 프로그램으로 다 음과 같은 기본적 취지를 가지고 진행되었다.

○ 타겟 고객인 대학생을 대상으로 하는 입체 적 마케팅을 통해, NESPOT 상품을 적극 적으로 알리고, 잠재고객으로 확보한다.

ㅇ 주요 참가자들을 NESPOT 모니터링 요원 화 하여 서비스 개선을 위한 피드백채널 로 활용한다.

앙후, 이에 연계하여 네스팟 주요 타겟 고 객 군들을 대상으로 하는 〈네스팟 오딧세 이>체험 이벤트를 지속적으로 개최, 실생 활속의 브랜드로 정착 추진한다.

〈체헙 마케팅을 통한 주류시장 진입을 위한 거점 확보>를 목적으로 2002년 하반기에 걸쳐 실시된 체헙 마케팅 프로그램을 통하여 네스팟 은 상당한 구전 효과를 얻을 수 있었다. 동시에 네스팟 서비스 체헙단들은 체헙 report, 즉, 서 비스 가입부터 고객 관리까지의 SO(Service Order)처리, 망 접속 안정성 및 노트북/PDA 단말의 적용성 등을 고객의 관점에서 제공함으 로써, 네스팟이 완전완비 제품으로서 한 단계 진화할 수 있도록 하는 계기를 만들었다. 또한 이들의 체험기가 당시 이슈화 되던 무선 랜에 대한 신문 및 인터넷 사이트를 통해 기사화됨 으로써, 캐즘 마케팅에서 중시하는 실용주의자 들과 보수주의자들의 대중적 관심을 유발시키 고, 기업이 아닌 자신과 관련 있는 사랍들의 객 관적인 의견을 통해 신상품의 정보를 얻고 이 를 통하여 구매를 결정하는 주류시장의 조기 다수 수용자 집단의 구매 특성을 충족시킴으로 써 매출과 연계되는 효과를 거둘 수 있었다. 


\section{$\mathrm{V}$. 성과 및 평가}

〈표 5-1〉는 15세 이상 44세 미만의 네스팟 고 객 중 주 1 희 이상 인터넷을 사용하는 800 명의 일반소비자를 대상으로 설문조사를 실시하여 성
별· 연령·인터넷이용 빈도·직업 등을 기준으로 4 개의 집단으로 분류한 자료이다. 이를 통해 네스 갓 상품이 성장기로 진입했으며, 마케팅 목표의 달성 및 성과 면에서 성공적임을 알 수 있었다.

남보다 앞서가며 신재품의 구매에 적극적인 '유형 1'은 네스팟이 초기 마케팅에서 타겟고객

〈표 5-1〉 제품 수명주기에 의한 네스팟의 고객 유형 분석

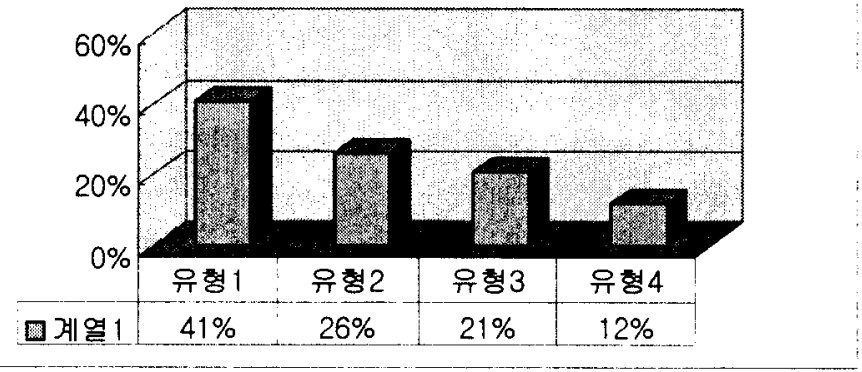

출처: 네스팟 마케팅 전략 자료(2002. 10)를 재구성

\begin{tabular}{|c|c|}
\hline 유형 & 특 \\
\hline 유형 I & $\begin{array}{l}\text { - 행동적 특성: 혁신적 수용자 및 조기 수용자 특성 } \\
\text { - 성별: 남성이 다수 } \\
\text { - 연령: } 20 \text { 30대 } \\
\text { - 인터넷이용: Medium\& Heavy User (1일 평균 } 3 \text { 시간 이상) } \\
\text { - 대표군: 전문직 }\end{array}$ \\
\hline 유형 II & $\begin{array}{l}\text { - 행동적 특성: 조기 수용자 특성 } \\
\text { - 성별: 남성이 다수 } \\
\text { - 연령: } 20 \text { - } 30 \text { 대 } \\
\text { - 인터넷이용: MediumUser (1일 1-2시간) } \\
\text { - 대표군: 화이트 칼라 }\end{array}$ \\
\hline 유형 III & $\begin{array}{l}\text { - 행동적 특성: 조기 수용자 특성 } \\
\text { - 성별: 남성이 다수 } \\
\text { - 연령: } 10 \text { - 20대 } \\
\text { - 인터넷이용: Heavy User } \\
\text { - 대표군: 학생 }\end{array}$ \\
\hline 유형 N & $\begin{array}{l}\text { - 행동적 톡성: 후기다수 및 최종수용자 특성 } \\
\text { - 성별: 여성이 다수 } \\
\text { - 연령: } 30 \text {-40대 인터넷이용: Light User } \\
\text { - 대표군: 주부 }\end{array}$ \\
\hline
\end{tabular}


층으로 정했던 〈혁신적 수용자 집단 및 조기 수용자 집단>으로 전체 네스팟 고객 중 $41 \%$ 를 차지하고 있는데. 이를 통해 네스팟이 혁신적 수용자 및 조기 수용자 기반을 확보하고 있음 을 알 수 있다.

둘째, 제품이 자신의 스타일 또는 이미지를 대표한다고 생각하는 '유형 2'와 제품의 특성을 냉철하고 철저히 분석한 후 검증된 제품만을 구입하는 '유형 3 '은 네스팟이 캐즘을 극복을 위한 마켸팅 전환을 통해서 재설정된 타겟인 〈조기 다수 수용자 집단〉으로, 유형 2 가 $26 \%$, 유형 3 이 $21 \%$ 로 전체 네스팟 고객의 $47 \%$ 를 차지하고 있다. 이는 네스팟의 주고객층이 조기 다수 수용자를 안정적으로 확보하고 있으며, 캐 즘을 극복하기 위한 주류시장으로 전진하고 있 음을 보여준다.

마지막으로 유형 4 는 유행이나 신제 품의 홍보 에 관심 없이 자신의 필요에 따라서 혹은 가장 늦게 서비스 가입에 참여하는 보수주의자 성향 의〈후기 다수 수용자 및 최종 수용자 집단〉으 로 현재 네스팟의 고객 중 가장 낮은 비율을 보이고 있다.

네스팟 마케팅 전략의 계량적 성과는 경쟁사 문제로 인해 수치를 발표하기 힘들지만, 2003년 이후 네스팟이 시장 진입기를 벗어나 매우 높 은 가입자 증가율을 기록하며 순조롭게 성장기 로 진입했으며, 타 경쟁 브랜드와는 시장점유율 에서 현격한 차이를 보이고 있어 네스팟의 마 케팅 전랴이 성공적이라 판단된다.

마케팅 전략의 수정 이후 얼게 된 이와 같은 성과를 바탕으로 네스팟의 지속적 성장을 위한 전략이 다음과 같은 방향으로 진행되고 있다. 첫째, 브랜드 체계의 대대적 정비. 소비자에게
브랜드가 알려지기 시작한 네스팟을 독자 브랜 드화 하여 상위 브랜드로 두고, 하위 브랜드로 패밀리-솔로-비즈-스윙으로 재정비 하는 작업 이 시작되었다. 패밀리(Family)는 1 가구 $2 \mathrm{PC}$ 이상 세대를, 솔로(SOLO)는 20-30대의 1가구 1노트북 세대, 비즈 $(\mathrm{Biz})$ 는 네스팟을 대량으로 구매하는 기업 대상, 스윙(Swing)은 이동통신 과 무선랜을 동시에 이용하는 PDA 및 스마트 폰 공급자를 타겟 고객으로 한다. 둘째, 완전완 비제품 구성을 위한 제휴 마케팅의 확대. 무선 랜이 장착된 게임기 제조업체 등과의 마케팅 협력을 강화하여 네스팟이 가능한 무선 단말 라인을 더욱 늘리며. 또한 압구정동, 대학로, 인 사동 등 네스팟 스트리트 구축을 통해 서비스 가능 지역을 넓히고 있다. 웹서비스 면에서도 메신저를 통한 유무선 통합 커뮤니케이션 서비 스(네스팟 아이맨 플러스)를 제공한다. 셋째. 네스팟 체헙의 확대. 네스팟의 체험 단원인 네 스팟 프리모(primo)는 2003년 결성되어 온라인 활동은 물론, 전국의 네스팟 존을 탐사하며 활 발한 활동을 계속하고 있으며, 경포대. 해운대 를 비롯한 각 지역에서 무선 초고속 인터넷 네 스팟 체험 이벤트를 계속해서 개최하고 있다.

지금까지 네스팟이 출시된 후 성장기 시장으 로 진입하는 과정에서 직면한 여러 문제점들과 이를 극복하기 위한 마케팅 전략을 살펴 보았 다. 이러한 분석과 검토는 첨단 기술을 기반으 로 하는 신제품이 새로운 시장을 개척함에 있 어서 발생할 수 있는 문제점들과 마케팅 전략 을 제시함으로써 유용한 시사점을 전해 줄 수 있을 것이라 생각된다.

〈논문 접수일: 2003. 9. 18〉 〈게재 확정일: 2004. 4. 23) 


\section{참고문헌}

제프리 A. 무어, 유승삼, 김기원 옮김(2002), 캐 즘 마케팅, 세종서적.

번트 슈미트 박성연, 윤성준, 홍성태 옮김(2002),

체험 마케팅, 세종서적.

심영식(2002), 초고속 무선 LAN서비스의 현

황과 미래, 삼성 SDS.
박진현(2002), 무선랜도입에 따른 무선랜 사 업의 유형과 국내 사업전략. $\mathrm{KISDI}$ 정보 통신정책, 제 14 권 9 호.

Sheth, Jagdish N.(1981), "Psychology of Innovation Resistance: The Less Developed Concept," Research in Marketing, 4, 273-82. 


\title{
New Product Marketing Strategy of Hi-Tech Communication Services: KT NESPOT Case
}

\author{
Ro, Ju Young* \\ Park, Seong-Yeon**
}

\begin{abstract}
This study introduces the marketing case of KT NESPOT, the new product marketing strategy of hi-tech communication services. Hi-tech products have different characteristics and the marketing strategy from introduction to growth stage is particularly important for the success of such products. This case explored the characteristics of hi-tech products, analyzed the marketing environments, and suggested how such new products can succeed in marketing.
\end{abstract}

Key words: NESPOT, hi-tech product, chasm marketing

* Assistant Researcher, KT Service Development Laboratory.

** Professor of Dept. of Business Administration. Ewha Womans University. 